NBER WORKING PAPER SERIES

\title{
FOREIGN INVESTMENT WITH \\ ENDOGENOUS PROTECTION
}

Gene Grossman

Elhanan Helpman

Working Paper No. 4876

\author{
NATIONAL BUREAU OF ECONOMIC RESEARCH \\ 1050 Massachusetts Avenue \\ Cambridge, MA 02138 \\ October 1994
}

We thank the National Science Foundation and the US-Israel Binational Science Foundation for financial support. Grossman also thanks the John S. Guggenheim Memorial Foundation, the Sumitomo Bank Fund, the Daiwa Bank Fund, and the Center of International Studies at Princeton University. Part of this work was carried out when the authors were visiting I.G.I.E.R. in Milan and when Grossman was at L.E.Q.A.M. in Aix-en-Provence. Needless to say, these were very hospitable environments. This paper is part of NBER's research program in International Trade and Investment. Any opinions expressed are those of the authors and not those of the National Bureau of Economic Research.

(c) 1994 by Gene Grossman and Elhanan Helpman. All rights reserved. Short sections of text, not to exceed two paragraphs, may be quoted without explicit permission provided that full credit, including (c) notice, is given to the source. 
NBER Working Paper \#4876

October 1994

FOREIGN INVESTMENT WITH

ENDOGENOUS PROTECTION

\begin{abstract}
Jagdish Bhagwati coined the phrase quid pro quo foreign investment to describe international investments made in anticipation of host country trade policy and perhaps with the intention of defusing a protectionist threat. We apply Bhagwati's notion to situations where (i) foreign investment is best described as the (uncoordinated) opening of branch plants by multinational corporations, and (ii) protection is a political response by an incumbent govemment to offers of policy-contingent campaign contributions by domestic firms. We examine the determinants of anticipatory foreign investment and study some of its welfare implications. We also allow for lobbying by workers with sector-specific skills and show how the conflicting interests of these workers and the industrialists are resolved in determining policy toward foreign investment.
\end{abstract}

Gene Grossman

Woodrow Wilson School

Princeton University

Princeton, NJ 08544-1013

and NBER
Elhanan Helpman

The Eitan Berglas School of Business

Tel Aviv University

Ramat Aviv, Tel Aviv

ISRAEL

and NBER 


\section{Introduction}

Jagdish Bhagwati coined the phrase quid pro quo foreign investment to describe in. vestments undertaken in anticipation of trade policy and perhaps with the intended purpose of defusing a protectionist threat. In a series of papers beginning with Bhagwati (1987), he and several colleagues and former students have explored the role that such direct foreign investment (DFI) may play in shaping tariffs, quotas, voluntary export restraints, and more. ${ }^{1}$ These authors typically took the probability of future protection to depend on the extent of import penetration and the stock of DFI, and viewed DFI as a transfer of capital from one country to another. In this context. firms move their capital and restrict their exports so as to maximize the expected present value of their profits, taking into account the effects of their investment decisions on subsequent policy formation. The foreign government is usually assumed to coordinate investment decisions, although occasionally it has been supposed that foreign oligopolists independently exploit the intertemporal ramifications of their actions (e.g., Dinopoulos, 1989). This literature-motivated in large part by the behavior of Japanese firms in the early and mid 1980's-has produced many interesting insights and has enriched our understanding of the link between foreign investment and the formation of trade policies.

Our aim in this paper is to extend Bhagwati's concept of anticipatory investment to situations where (i) DFI is best seen as the opening of a subsidiary by a multinational corporation and (ii) trade policy represents an optimal political response by politicians to the pressures applied by special interest groups. We follow Markusen (1984) and Helpman (1984) in modeling multinational investment as the costly es. tablishment of a branch plant by a firm that has the exclusive right or the exclusive ability to manufacture a particular product. The foreign owners of such an intangible asset face a choice between bearing the cost of opening a new subsidiary and producing in their existing parent facility. In making this choice. they recognize that

\footnotetext{
1See, for example, Bhagwati, Brecher et al. (1987), Dinopoulos (1989, 1992), Wong (1989). Bhagwati, Dinopoulos et al. (1992).
} 
their attempts to export may be impeded by subsequent home-country trade barriers. We combine this view of DFI with the approach to policy formation that we developed in Grossman and Helpman (1994a). We suppose that an incumbent gov. ernment receives offers of campaign contributions that are (at least implicitly) tied to its ultimate policy actions. It sets policy with a view toward the trade-off between the extra contributions that may be associated with protectionist interventions and the loss of voter goodwill that may be a consequence thereof. At first we assume that there is only one organized interest group attempting to influence policy, namely a lobby representing domestic firms in the industry with DFI. Later we allow also for contributions from a lobby representing domestic workers with skills specific to the industry.

Prospective multinationals anticipate the mechanism by which policy will be set when they make their foreign investment decisions. We treat DFI as a decentralized process wherein each foreign company takes the investment decisions of the others as beyond its control. Given the extent of DFI by other companies, each firm forms expectations about the host country's eventual trade policy and evaluates the prof. itability of its own potential foreign investment accordingly. A firm establishes a subsidiary if by doing so it can earn greater profits net of investment costs than it can by exporting from its parent facility. It recognizes that the cost of opening a foreign subsidiary cannot be recovered once the investment has been made. Finally, an equilibrium entails a level of DFI and a rate of protection such that the political process supports the particular rate of protection as an outcome in the stage game, and the expectations about protection that foreign firms hold when they make their investment decisions are fulfilled. ${ }^{2}$

\footnotetext{
${ }^{2}$ Bordtmann and Markusen (1992) have studied how protection affects the equilibrium level of DFI under the amption that home-country trade policy is exogenously given. Meanwhile, Hillman and Uroprung (1993) have examined how the extent of multinational investment influences the determination of trade policy, given the numbers of national and multinational firms. Our analyois is distinguished by the fact that we treat both multinational investment and trade policy as endogenously (and jointly) determined.
} 
We develop the basic model in section 2. This is followed in section 3 by an analysis of the determinants of equilibrium tariffs and levels of DFI. There often exists a single, stable equilibrium. However, if the cost of opening a subsidiary is small and politicians happen to place great weight on the well being of the average voter, then two stable equilibria may coexist. In one of these equilibria no DFI takes place, while in the other all foreign firms establish offshore production facilities. We show that, whenever only a fraction of foreign companies choose to build plants in the home country, an increase in the fixed cost of foreign investment reduces the number of multinationals in equilibrium. Also, the greater the home government's concern for the plight of the average voter, the smaller is the extent of multinationality. When the politicians' concern for the average voter's is great and the cost of DFI is low. an increase in the weight attached to average welfare results in a higher rate of protection.

These results suggest some interesting efficiency properties of our model. To explore these, we develop in section 4 a measure of net welfare that allows for the possibility that some (and perhaps all) of the contributions to politicians are wasted in the course of the election campaign. Using this notion of net welfare, we ask. Do restrictions on DFI raise net welfare? And does a government that attaches greater weight to the interests of the average voter necessarily deliver a higher standard of living? The first question is particularly interesting when manufacturing costs happen to be higher in the home country than abroad. Then restricting the entry of foreign multinationals diverts production to the lower cost country, but also creates a political climate in which special interests readily can lobby for protection. In such circumstances, restrictions on DFI can be especially costly. As for the second question. it appears that a change in the political environment that causes the government to weigh more heavily the concerns of the average voter might fail to generate an increase in net welfare. This is because such a change in the political climate might lead to a higher level of equilibrium protection and it might induce interest groups to deliver a higher level of wasteful contributions. However, somewhat comfortingly, we found that extensive simulations of the model failed to turn up a single case where a more 
public-minded government would deliver a lower level of average net welfare.

In section 5 we extend the model to account for the interests of workers with skills specific to the sector with DFI. We show that the interests of these workers are closely aligned with the interests of the domestic manufacturers on the issue of trade protection. Given the level of DFI, both wage earners and profit recipients gain from an increase in the tariff. However, on the issue of policy toward foreign multinationals. the two interest groups are bound to conflict. Domestic manufacturers would benefit from any restriction on DFI, whereas the workers with specific human capital would be harmed by such a policy. If elected officials can regulate policy toward multinationals. the extent of DFI in equilibrium depends on the relative political strengths of the two competing interest groups. We examine the determinants of "political strength" in this particular context.

\section{Basic Model}

The home country produces a numeraire good with unskilled labor alone. One unit of labor is required per unit of output. Thus, the equilibrium wage equals 1 . The home country also manufactures an assortment of brands of a differentiated product. Each brand requires a fixed amount of unskilled labor per unit of output. For the time being, we assume that no other inputs are needed. The number and types of the domestic products are treated as given throughout.

The domestic manufacturers of differentiated products compete with a fixed set of foreign brands. Each foreign supplier faces a choice. It can assemble its product in an already-existing plant in its native country or it can build (or purchase) a new. production facility in the home country. The choice between exporting and foreign investment is made based on a comparison of expected profits, where profits from a potential subsidiary are calculated net of the fixed costs of building the facility. These costs, which must be borne before the home country finally sets its trade policy, cannot be recouped in the event that the plant is not used. Thus, each foreign 
company must form some expectations about the likely outcome of the home country's political process. ${ }^{3}$ We focus on equilibria with self-fulfilling expectations.

After the foreign investment takes place, the home government sets a tariff on imported varieties of the differentiated product. The level of the policy reffects the conflicting political pressures it faces. On the one hand, the government is concerned with the welfare of the average voter, because its prospects for re-election depend on the standard of living it provides. On the other hand, it conceivably can collect political contributions from the special interest groups to which it caters. We assume that the domestic lobbies-which, to begin with, comprise only a single group representing the domestic manufacturers of brands of the differentiated product - offer donations that are contingent on the tariff imposed by the government. Presumably, a higher tariff will elicit a larger contribution from the domestic industry, although the interest group is free to design its contribution schedule in any way it chooses. Faced with the contribution schedule, the government sets the policy that maximizes its own political objective function. We take the latter to be a simple weighted sum of total campaign gifts and average welfare." All of this is well understood by the foreign companies at the time that they must make their entry decisions.

We now describe the domestic economy in more detail.

\footnotetext{
${ }^{3}$ We choose this order of play in order to emphasize that in vestments in plant and equipment are often irreversible, whereas policy can be changed by the government at will. In these circumstances. foreign firms must realize that long-run trade policy will refiect political conditions prevailing after all decisions regarding DFI are made.

-This political objective function can be derived as a reduced form of a game in which the incumbent government must compete in an election with an opposition party. See Grossman and Helpman (19946).
} 


\subsection{Consumption and production}

The home country is populated by a continuum of individuals with measure 1 . The utility function of each individual is given by

$$
U=x_{0}+\frac{\theta-1}{\theta} x^{(\theta-1) / \theta} . \quad \theta>1 .
$$

where $x_{0}$ represents consumption of the numeraire good and $\boldsymbol{I}$ is an index of con. sumption of the differentiated products. The consumption index takes the form

$$
I=\left[\int_{j \in N_{h}} x(j)^{(\varepsilon-1) / \epsilon} d j+\int_{j \in N_{l}} x(j)^{(e-1) / e} d j\right]^{e /(e-1)}, \quad \epsilon>1 .
$$

where $x(j)$ denotes consumption of brand $j$, and $V_{h}$ and $N_{j}$ are the sets of brands manufactured by home and foreign firms, respectively (the latter either in a native plant or in a subsidiary located in the home country).

As is well known, this structure of preferences yields constant-elasticity demand functions for each brand, with $\epsilon$ being the elasticity of demand. In fact. given the two-tier structure of preferences, the demand for any brand $j$ can be represented by

$$
x(j)=p(j)^{-\ell} q^{e-\theta}
$$

where $p(j)$ is the price of brand $j$ and $q$ is a price index for all differentiated products. We assume that $\epsilon>\theta$, which implies that the different brands substitute more closely for one another than they do for the numeraire good. This assumption ensures a positive cross-elasticity of demand. That is, an increase in the price of competing brands always causes substitution from these brands to variety $j$. At the same time. it raises the price index $q$, which causes consumers to substitute the numeraire good for the entire group of differentiated products. When $\epsilon>\theta$, the former effect dominates and the demand for good $j$ increases.

Each manufacturer of a brand of the differentiated product maximizes profits by equating marginal revenue to marginal cost. A foreign firm manufacturing in its native facility faces the constant marginal cost $c_{f}$. In the home country, $c_{h}$ units of labor are needed to produce a unit of any brand of the differentiated product. This 
means that the marginal cost for home firms and foreign subsidiaries is also $c_{h}$. since the wage rate equals 1 . The mark-up pricing rule then implies

$$
p(j)=\left\{\begin{array}{cl}
p_{h} \equiv \frac{c}{\epsilon-1} c_{h} & \text { for } j \text { manufactured in the home country, } \\
p_{f} \equiv \frac{c}{\epsilon-1} c_{f} \tau & \text { for } j \text { manufactured in the foreign country. }
\end{array}\right.
$$

where $p_{i}, i=h, f$, denotes the consumer price of a variety manufactured in country $i$ and $\tau$ represents one plus the ad valorem tariff rate. We denote by $n_{h}$ the number of brands owned by home-country firms (the measure of the set $N_{k}$ ) and by $n_{f}$ the number of brands owned by foreign firms (the measure of the set $N_{f}$ ). In addition, we let $m$ denote the number of foreign firms that have established production facilities in the home country. Then the price index for $x$ can be written as

$$
q=\left[\left(n_{h}+m\right) p_{h}^{1-\epsilon}+\left(n_{f}-m\right) p_{f}^{1-\epsilon}\right]^{\frac{1}{1-\epsilon}} .
$$

assuming that all foreign firms with subsidiaries in the home country actually use these facilities to produce their output. ${ }^{3}$ Finally we calculate output levels and operating profits (i.e., revenue minus manufacturing costs) for firms producing in each location. which gives

$$
\begin{gathered}
x_{i}=p_{i}^{-\epsilon} q^{\ell-\theta} \quad \text { for } i=h, f, \\
\pi_{i}=\frac{1}{\epsilon T_{i}} p_{i}^{1-\epsilon} q^{e-\theta} \quad \text { for } i=h, f .
\end{gathered}
$$

Here, $\pi_{i}$ represents the operating profits derived from a single brand and we use the notational convention that $\tau_{h}=1$ and $\tau_{f}=\tau$.

For the time being we assume that the tariff is the only policy instrument available to the government. The government redistributes any tariff proceeds to the voters on an equal, per capita basis. We can now use (1) to express the average (gross) welfare level of a citizen in the home country as a function of the tariff rate and the number

\footnotetext{
"If this is not the case, then $m$ in (3) should be replaced by the numbet of multinationals that supply the home market with output produced in their subsidiaries. Of coutse, in an equilibrium with fulfilled expectations, sll firms that make costly investments in foreign plants will use these plants for production.
} 
of products supplied by subsidiaries of multinational corporations. We have

$$
W(\tau ; m)=L+n_{h} \pi_{h}+\frac{\tau-1}{\tau}\left(n_{f}-m\right) p_{j} x_{f}+\frac{1}{\theta-1} q^{-! \theta-1 !} .
$$

where $L$ is average labor income in view of an assumed inelastic supply and the fact that the wage rate is equal to 1 . The remaining terms on the right-hand side represent average profit income, the average tariff rebate, and the average surplus derived from the consumption of differentiated products, respectively. The complete functional dependence of $W$ on $r$ and $m$ is obtained by substituting equations (2)-(5) into (6).

\subsection{The special interest group and the government}

The government chooses the rate of protection $\tau$ to maximize its political objective function, which we take to be linear in political contributions and the average welfare of voters. In selecting a trade policy the government faces a contribution schedule $C(\tau) \geq 0$ that has been proposed by the domestic lobby group. We write the governments' objective function as

$$
G=C(r)+a W(r ; m)
$$

where $a>0$ is the weight that the government attaches to (gross) voter welfare relative to political contributions.

The lobby represents all of the home-country manufacturers of differentiated products. Somehow they overcome Mancur Olson's "collective-action" problem (see Olson. 1965) and coordinate their efforts to influence policy. Multinational corporations with subsidiaries in the bome country do not participate in lobbying for protection. We assume for simplicity that the set of voters who own shares in companies that produce brands of the differentiated product is of measure zero. In the event, owners of home firms instruct their lobby to design a contribution schedule that maximizes their joint profits net of campaign contributions. In short, we take the lobby's objective to be the maximization of $n_{h} \pi_{h}-C$.

The lobby's leaders know that once a contribution schedule has been proposed to the politicians, the latter will set policy to maximize (7). Moreover, they know 
that they cannot drive the politicians' welfare below the level that the latter could attain by declining all contribution offers. The government's reservation welfare level is given by $a W^{*}(m)$, where

$$
W^{\bullet}(m)=\max _{\tau} W(\tau ; m)
$$

The curve $G^{*} G^{*}$ in Figure 1 depicts the combinations of contributions and tariff levels that yield the government a value of $G$ equal to $a W^{-}(m)$. Curves above $G G$ represent government indifference curves with higher welfare levels. If the lobby designs a contribution schedule that is located everywhere below $G^{*} G^{*}$, the government will choose $\tau^{-}$, which secures its reservation welfare. In view of this, the best the lobby can do is to induce the government to choose point $A$, where the lobby's own indifference curve $L^{-} L^{*}$ is tangent to the government's indifference curve. Clearly, there are many contribution schedules that will generate this outcome; one example is a contribution schedule that coincides with the horizontal axis to the left of the lowermost point of $L^{-} L^{*}$ and coincides with $L^{*} L^{*}$ to the right of that point.

Our argument suggests that the lobby implicitly solves the problem:

$$
\begin{gathered}
\max _{\tau, C} \quad n_{h} \pi_{h}-C \\
\text { s.t. } C+a W(\tau ; m) \geq a W^{*}(m) \text { and } C \geq 0 .
\end{gathered}
$$

Thus, the political equilibrium is characterized by a tariff that maximizes the joint welfare of the lobby and the government (i.e., $\tau^{p}=\arg \max _{r}\left[n_{h} \pi_{h}+a W\{\tau ; m\}\right]$ ) and a level of contributions that satisfies the participation constraint with equality (i.e., $\left.C^{p}=\left[a W^{*}\{m\}-W\left\{\tau^{p} ; m\right\}\right]\right)$.

Using (6), we can express the equilibrium tariff as

$$
\tau^{p}=\arg \max \left[(1+a) n_{h} \pi_{h}+a \frac{\tau-1}{\tau}\left(n_{f}-m\right) p_{f} x_{f}+a \frac{1}{\theta-1} q^{-(\theta-1)}\right] .
$$

When written in this way, we see that the political tariff maximizes a weighted sum of profits, tariff revenue, and consumer surplus. Whereas these components would receive equal weight from a benevolent social planner, the political process gives greater 
weight to the profits, which accrue to an organized interest group, and relatively less to the tariff revenue and consumer surplus, which go to the general public. Viext we can use the first-order condition for (9) together with (2)-(5), to derive an implicit formula for the equilibrium tariff, namely

$$
\frac{\tau^{p}-1}{\tau^{p}}=\frac{1+a}{a \epsilon} \frac{(\epsilon-\theta) n_{h}}{\epsilon\left(n_{h}+m\right)+\theta\left(n_{f}-m\right)\left(\tau^{p} c_{f} / c_{h}\right)^{1-\ell}} .
$$

This tariff applies provided that $m<n_{f}$ and so long as the equation has a solution with $\tau^{p}>\left(c_{h} / c_{f}\right)^{(e-1) / e}$. The latter condition ensures that foreign multinationals who have invested in subsidiaries will use these facilities to serve the home market. Otherwise, the multinationals leave their subsidiaries idle, and the home government sets the tariff $r^{p}=\left(c_{h} / c_{f}\right)^{(<-1) / c}$. Finally, when all foreign companies establish subsidiaries in the home country (i.e., $m=n_{f}$ ) any tariff level $\tau^{p} \geq\left(c_{h} / c_{f}\right)^{(\ell-1) / e}$ solves the maximization problem, because variations in the tariff rate have no real effects as long as the tariff is high enough to induce the multinationals to make use of their offshore production facilities. ${ }^{6}$

\subsection{Multinationals}

We now turn to the first stage, when each foreign firm must decide whether to invest in a foreign subsidiary. We will assume that the entry process is decentralized; that is, each firm makes its own decision taking those of all of the other companies as given. Given its beliefs about aggregate DFI, each firm forms expectations about the tariff rate using (9).? Then it calculates the difference between expected profits from operating a subsidiary and expected profits from exporting. Finally, it compares this

\footnotetext{
${ }^{\circ}$ Our discumion in the lext ignores one last possibility. It may happen that. given $m$, a choice of $\tau^{\prime \prime}<\left(c_{h} / r_{f}\right)^{(1-1) / c}$, which is low enough to make the multinationals export to the home market. provides higher joint welfare to the lobby and the government than any policy with $r^{p}>\left(c_{n} / c_{l}\right)^{1 t-11 / c}$. This case cannot arise in equilibrium, however, because foreign firms would not bear the positive cost of DFI if they expected such a low tariff.

${ }^{7}$ With a continuum of firms, the aggregate amount of DFl is independent of the decision of any one fitm.
} 
difference to the fixed cost, $\phi$, of establishing an offshore facility.

From (2)-(5) we can calculate the difference in operating profits as a function of the tariff level and the number of subsidiaries. The result is

$$
\pi_{h}-\pi_{f} \equiv \delta(\tau ; m)=\frac{B\left(c_{h}^{1-\ell}-\tau^{-\ell} c_{f}^{1-c}\right)}{\left[\left(n_{h}+m\right) c_{h}^{1-\ell}+\left(n_{f}-m\right)\left(\tau c_{f}\right)^{1-\ell}\right]^{(\ell-\theta) /(\epsilon-1)}} .
$$

where $B=\epsilon^{-\theta}(\epsilon-1)^{\theta-1}>0$. A foreign company expecting the tariff rate to be $\tau$ and observing a measure $m$ of foreign firms establishing subsidiaries in the home country will invest itself if $\delta(\tau ; m)>\phi$. If $\delta(\tau ; m)<\phi$, the company will certainly not open a branch plant, while if the two are equal, it is indifferent between the two options.

An alternative to our specification would allow coordinated entry by foreign multinationals. This would be appropriate if foreign companies could collude in making their investment decisions or if the foreign government were inclined to regulate DFI. In either of these cases, $m$ would be chosen to maximize $(\delta-\phi) m+n_{f} \pi_{f}$, recognizing the dependence of the endogenous tariff rate on the choice of $m$ (via [9]). This alternative setup would be closer in spirit to the formulation suggested by Bhagwati (1987) and explicitly analyzed in Bhagwati, Brecher, et al. (1989). We will not pursue it any further here.

\section{DFI and Protection}

We seek to characterize perfect-foresight equilibria. In what follows we assume that manufacturing costs are higher in the home country; i.e., $c_{h}>c_{f}$.

\subsection{Tariff response curves}

Figure 2 depicts two tariff response curves, each describing the political tariff as a function of $m$ for a particular set of parameter values. These curves are derived from (9). It is easy to verify that all curves above the broken horizontal line at

\footnotetext{
'Equation (10) does not always provide a unique solution for $\tau^{p}$ as a function of $m$. Two solutions exist, for example, when $m=0, a=0.217, c=2, \theta=1.1, c_{h}=5, c_{f}=1 . n_{h}=1$, and $n_{l}=1$
} 
$\dot{\tau}=\left(c_{h} / c_{f}\right)(\theta / \epsilon)^{1 /(e-1)}$ slope downwards, and that all curves below this line but above the horizontal line at $I=\left(c_{h} / c_{f}\right)^{(c-1) / c}$ slope upwards. ${ }^{9}$ Tariff response curves below I are horizontal, because with such low tariffs any multinational that happened to own a subsidiary in the home country would not use its local plant to supply the home market in any case. We restrict our attention to parameters that give a political tariff at least as high as $I$. Note that the figure is drawn under the assumption that $\dot{\tau}>I$, but this need not be the case. If $\dot{\tau}<I$, then all tariff response curves slope downward. Finally, recall the discussion following equation (10), where we argued that in the limiting case where $m=n_{f}$ (i.e., when all foreign companies establish subsidiaries in the home country), the political tariff can take any value at least as large as $I$, because all of these tariffs solve (9) and all result in the same allocation of resources.

We note for later reference that, when the parameter a rises, the tariff response curve shifts down. In other words, were the political climate to change so that the government placed relatively greater weight on per capita welfare, the equilibrium tariff would be lower for every (given) degree of multinationality.

\subsection{Profit differential curves}

We show in Figure 3 five profit differential curves, each one representing a given difference between the operating profits of a firm manufacturing in the home country and one manufacturing in the foreign country, as described by (11). A higher curve corresponds to a greater profit differential. When one plus the tariff rate equals the cost ratio $c_{h} / c_{f}$, the profit differential does not depend on the degree of multinationality $m$ (i.e., the curve is a horizontal line). For higher tariffs than this: the curves slope upward whereas for lower rates they slope downward. A very large profit differential In this case neither one of them solves (9); the solution to (9) is instead an infinite tariff. Equation (10) can be inverted, however, to express $m$ as a function of $\tau^{p}$.

'We should emphasize the ambiguity in the slope of the tariff response function. Most of the literature that follows Bhagwati assumes a priori that an increase in the number of multinationals reduces the expected rate of protection. 
that can arise when $m=0$ may not be possible even with an infinite tariff for some positive values of $m<n_{f}$; this is reflected in our depiction of the uppermost curve in the figure.

\subsection{Entry}

Every foreign company compares the profit differential with the fixed cost $\phi$, alter forming some expectation about the future tariff. Let $\tau^{e}(m)$ describe (one plus) the tariff rate that a foreign firm expects when the number of multinationals equals $m$. Then there are three possible equilibrium configurations:

- $m=0$ and $\delta\left[\tau^{e}(0), 0\right] \leq \phi$

- $0<m<n$, and $\delta\left[\tau^{e}(m), m\right]=\phi_{\text {; }}$

- $m=n_{f}$ and $\delta\left[\tau^{e}\left(n_{f}\right), n_{f}\right] \geq \phi$

In the first case no DFI occurs and no firm finds it profitable to enter on its own. In the second case some multinationals form and net profits for a firm that establishes a subsidiary are the same as for one that does not. In the third case all foreign firms form subsidiaries and net profits are at least as high as the profits that a single firm would attain if it refrained from investing in the home country.

As we will see in a moment, occasionally more than one of these types of equilibria can exist for given parameters. When this happens we shall select among them on the basis of a stability criterion. We adopt the following (ad hoc, but intuitive) adjustment process:

$$
\dot{m}=M\left(\delta\left[\tau^{e}(m), m\right]-\phi\right), \text { for } 0<m<n_{f}
$$

where $M(0)=0$ and $M(\cdot)$ is an increasing function for $\delta-\phi>0$. This process presumes that, whenever the existing number of subsidiaries is such that it would be profitable for a single firm to invest, the number of subsidiaries rises; and whenever 
it would be profitable for a single firm to refrain from investing, the number of sub. sidiaries falls. Of course, this "adjustment" does not take place in real time: recall that the fixed costs of purchasing a subsidiary are assumed to be sunk, once incurred.

\subsection{Equilibrium DFI and protection}

We now combine these elements in order to characterize the stable, perfect-foresight equilibria. Figure 4 depicts a case with a high fixed cost of entry $\phi$ and a low value of $a$. The latter means that the government is primarily concerned with amassing campaign contributions. As a consequence of these parameter restrictions, the tariff response curve and the profit differential curve corresponding to a difference of 0 both lie everywhere above the cost ratio $c_{h} / c_{f}$ for all relevant values of $m$. This means that the tariff response curve TT slopes downward while the relevant profit differential curve $\Pi \Pi$ slopes upward.

The point $A$ in the figure represents a perfect-foresight equilibrium. So do all points on the vertical line above point $B$. In the former case, penetration of foreign multinationals is partial, and a firm that invests in the home country enjoys the same net profit as one that serves the home market with exports. In the latter case(s). all foreign firms establish subsidiaries and the ensuing political tariff causes none of them to regret its decision. Note, however, that these latter equilibria are all unstable. If, for example, the number of multinationals were slightly less than $n_{f}$, then the expected tariff would be on the tariff response curve below $B$, causing a reduction in the multinationals, an increase in the expected tariff, and so on, until the economy converged (following the arrows) to the equilibrium at point $A$.

To clarify the source of the instability, it may help to think as follows. Each foreign frm knows that if all others establish subsidiaries, the home government will be indifferent among all tariffs above $I$. In consequence, the government would indeed be willing to choose a tariff above the one at point $\mathrm{B}$, which would sustain an equilibrium there. But the firm also knows that if a single other foreign firm were to refrain from investing in the home country, the political tariff would be well below 
that at point $B$. If this were to happen, the firm would very much regret any decision to invest. So it might decide not to take the risk. If all firms think in this way, they will all be led to expect the tariff at $A$ and to make their investment decisions accordingly.

We now can examine the effects of varying the underlying parameters slightly. We focus on the cost of entry and the degree to which the government cares about the average voter. First consider the parameter $a$. The less weight the government attaches to per capita welfare (lower $a$ ) the higher is the tariff response curve and the higher is point $A$ on the profit differential curve. The result is a higher rate of protection and a greater presence of foreign multinationals. Now consider the cost of entry. When $\phi$ is lower, so too is the relevant profit differential curve and the location of point $A$ along the tariff response curve. It follows that DFI is greater and protection lower the lower are the costs of foreign entry.

Figure 5 depicts another possible situation, which can arise when the government cares significantly about welfare, entry costs are low, and $\dot{\tau}<I .{ }^{10}$ In this case, point $A$ again represents the unique, stable equilibrium (as before, the arrows indicate the adjustment path). Here again lower entry costs imply a greater number of foreign subsidiaries and a lower rate of protection. But, unlike in the previous case, now if the government were to concern itself more with contributions and less with per capita welfare, the tariff rate would fall.

A comparison of the two cases depicted in Figures 4 and 5 suggests the absence of a clear-cut relationship between a government's willingness to cater to special interests and the degree of protection that ultimately obtains. The reason is that foreign firms make their investment decisions in anticipation of policy formation and their decisions can alter the political climate in which the tariffs are eventually determined. In both cases the direct effect of a decrease in a (given $m$ ) is to generate an incipient increase in the expected tariff; in both cases this induces more foreign firms to enter; and in both cases recognition of this entry causes expectations of the tariff increase to

\footnotetext{
${ }^{10}$ This requires $c_{h} / c_{f}<(\epsilon / \theta)^{c /(c-1)}$.
} 
moderate. In the case depicted by Figure 4, the entry of multinationals does not cause the tariff to fall below its initial level. But in the case depicted in Figure 5 . the assumed adjustment process indeed leads this to happen.

Figure 6 depicts still another possibility. This situation can arise when the politicians place a great weight on voter welfare and when fixed costs of forming a subsidiary are low. It also requires $\dot{\tau}>I$. Here there are two stable, perfect-foresight equilibria. at points $A$ and $C$ (whereas the equilibrium at point $B$ is unstable). If all foreign firms were to refrain from investing, as at point $A$, the political tariff would be reasonably low. Then the firms that had expected this low tariff would be happy they had chosen to export from their home plants. On the other hand. if all foreign firms were to form subsidiaries, as at point $C$, then the political tariff would be high, and the firms would be glad to have their production facilities inside the protected market.

The comparative statics are simple in this case. Neither a small change in the government's utility weights nor a small change in the fixed cost of entry has any effect on the existence of the two extreme equilibria. If a were dramatically lower, however, the TT curve would lie everywhere above the ПП curve, and then the unique equilibrium for firms expecting very high tariffs (at all $m$ ) entails entry by all. Similarly, if $\phi$ were dramatically lower, the $\Pi \Pi$ curve would lie below TT, and again all would enter. Finally, if either $a$ or $\phi$ were much higher than as depicted in the figure, the unique equilibrium would have low tariffs or prohibitive entry costs, and no MNC's in either case.

\section{Welfare}

Our analysis has focused on the joint determination of direct foreign investment and the rate of protection when domestic companies lobby for protection. The resulting equilibrium has, of course, implications for the well being of the general electorate. There are many interesting welfare questions that one could address with our model. In this section, we concentrate on two that may be particularly interesting. 
Before we can address any normative issues, however. we need to be precise about our welfare metric. Equation (6) gives the gross welfare of the average voter. But this measure includes the contributions paid by members of interest groups. These contributions might represent a pure transfer to politicians or perhaps they will be put to some socially productive use in the course of an election campaign. Alternatively. we might believe that the contributions will be used to finance some socially wasteful electioneering activities. To evaluate which of these views is appropriate. we would need a fully articulated model of the election process, which is beyond our scope here. So instead, we introduce a welfare measure that admits alternative interpretations. We define net welfare as

$$
N \equiv W(\tau ; m)-\gamma C
$$

where $\gamma$ is a parameter ranging from 0 to 1 . We use this parameter to reflect the extent to which campaign contributions represent a social deadweight loss.

\subsection{Does DFI benefit the average voter?}

First we examine whether DFI proves beneficial to the average voter in the host country. Interest in this question arises from the fact that governments may have the ability to restrict multinational investment by fiat, and if so, domestic interest groups may have an incentive to lobby for such restrictions. It might seem that such restrictions would be harmless to the average voter in our context, because manufacturing costs are higher at home than abroad. By restricting DFI, the home country ensures a cheap source of supply and so can secure a favorable terms of trade. However, this reasoning proves only partially correct in the light of the politicaleconomic response to investment restrictions.

To demonstrate the possibility that impediments to DFI may harm the average voter, we consider a situation where the government attaches very little weight to the public interest and the fixed cost of establishing a subsidiary is relatively low. In the event, the unique stable equilibrium when DFI is permitted has entry by all foreign firms $\left(m=n_{f}\right)$ and a tariff high enough to ensure that all these firms actively use 
their subsidiaries. Moreover, once all foreign firms have built their plants in the home country, gross welfare of the average voter does not depend on the tariff rate (provided that $T-1>c_{h}\left(c_{f}\right)$. This means that the government may be happy to provide the equilibrium protection without contributions from the interest group. If so. then net welfare would equal gross welfare, which in turn could be expressed (using $(2]-[6])$ as

$$
\tilde{W}(q) \equiv L+n_{h} p_{h}^{1-e} q^{e-\theta}+\frac{1}{\theta-1} q^{-(\theta-1)}
$$

for $q=\left(n_{h}+n_{f}\right)^{1 /(1-\epsilon)} p_{h}$.

Now compare this outcome to the one that would obtain if foreign investment were prohibited. A government that cared little about average welfare would cater readily to the interest group. It would be induced by the group to choose the tariff that maximized domestic profits, which in this case is a prohibitive one. Moreover, it would require only a minuscule contribution in order to provide such protection. It follows that net welfare again would equal gross welfare, and that the latter would again be given by (14), but this time with $q=n_{h}{ }^{1 /(1-\ell)} p_{h}$. Our comparison thus hinges on whether $\tilde{W}\left[\left(n_{h}+n_{f}\right)^{1 /(1-\epsilon)} p_{h}\right]$ exceeds $\dot{W}\left(n_{h}^{1 /(1-e)} p_{h}\right)$, or vice versa.

The function $\tilde{W}(q)$ may be everywhere increasing in $q$ for $q$ in the range between $n_{h}^{1 /(1-\epsilon)} p_{h}$ and $\left(n_{h}+n_{f}\right)^{3 /(1-\epsilon)} p_{h} .^{11}$ In the event, the average voter must be harmed by a prohibition on foreign investment. The source of the welfare loss is in the political economy of the situation. Whereas the anticipatory foreign investment allows domestic consumers to enjoy some surplus from foreign varieties, they would realize no such surplus in an equilibrium without DFI in which the government was induced to erect prohibitive trade barriers. Alternatively, if $\tilde{W}(q)$ happens not to be increasing in $q$ throughout the relevant range, then a restriction on DFI may or may not be costly to the average voter; but it must be so if the number of foreign brands is large.

The fact that restrictions on DFI may harm the average voter does not of course mean that foreign firms will be able to enter freely in a political equilibrium. The domestic industry has the same incentive to lobby for barriers to investment as it has

\footnotetext{
${ }^{13}$ We calculate that $d \tilde{W}(q) / d n_{f}$ has the same sign as $1-(\epsilon-\theta) p_{h}^{1-(}\left(\frac{n_{1}}{n_{n}+n_{f}}\right)$.
} 
to lobby for impediments to trade. So we might expect politics to stand in the way of quid pro quo foreign investment just as it restricts potentially gainful trade. However, we shall find in Section 5 that there is an important difference in the political economy bearing on these alternative policies; whereas all powerful domestic interest groups are likely to unite in opposition to imports, workers with industry-specific skills may well have an incentive to oppose domestic firms in their efforts to limit DFI.

\subsection{Does the average voter prefer a responsive government?}

Our second question concerns the normative properties of the political regime. One might hope that the average voter would benefit from having a government in place that weighs more heavily the public's well-being and that gives less weight to contributions from special interest groups. In our model, however, there is reason to hesitate before drawing this conclusion. It appears that the average voter might actually benefit from having the government cater more readily to domestic pressure groups, if as a consequence of this there would be a lower rate of equilibrium protection or a lower level of wasteful political contributions.

Consider for example the equilibrium depicted in Figure 7. Here, all foreign firms establish subsidiaries in the home country. The government might be willing to provide the associated protection even if it did not receive any campaign contributions for doing so, because gross welfare might be higher when the foreign firms produce locally as compared to exporting, once all such firms have already established a local presence. Assuming this were so, net welfare would equal gross welfare in the initial situation. Now if the political climate were to change in such a way that the government placed less weight on campaign contributions, the curve TT would be located lower in the figure. The equilibrium would instead be at a point such as $B$. with only partial penetration by foreign multinationals. There would be fewer foreign subsidiaries, which has ambiguous welfare implications, but also a higher rate of protection, which would contribute to a lower level of gross welfare. Also, domestic lobbies would have to pay to sustain the equilibrium tariff, so net welfare would fall 
short of gross welfare if $\gamma>0$. In principle, these effects might be strong to more than offset the direct benefit to the average voter from having a government that is more attuned to the general electorate.

Although we have been unable to rule out the paradoxical possibility just described, it appears not to be characteristic feature of our model. We have conducted extensive simulations of the model using a wide range of parameter values. These simulations failed to turn up a single case where an increase in the parameter $a$ would result in a reduction in net welfare. It is somewhat conforting to know that, at least in this context, a political reform that would reduce politicians' thirst for campaign contributions would typically benefit the average voter.

\section{Workers vs. Capitalists}

The profits of the domestic industry depend on the extent of the local presence of foreign frms on the one hand, and on the degree of protection against their export sales on the other. We have explored these links in some detail. taking account of the political economy of policy formation. Our discussion has focused mostly on the implementation of import tariffs, although we have noted in passing that a similar political dynamic might lead to impediments to DFI. Like trade barriers, such restrictions could prove costly to the average voter.

Our basic specification misses, however, an important distinction between the politics of protectionism and the politics of investment barriers. Because we have modeled an economy where skills are general and labor freely mobile, workers' interests have not been tied to their sector of employment. In reality, of course, workers often acquire skills that are specific to an industry. Then these workers gain a stake in the policies that affect their industry. Often we see organized labor as a distinct interest group lobbying the government. And, whereas the interests of wage-earners align closely with those of profit-earners on issues of protection, this may not be the case where policy toward DFI is concerned. 
To explore this point in more detail, we propose a simple modification to our model. We suppose now that differentiated products are manufactured with both "skilled" (or specific) and "unskilled" (or general) labor, and that the skills are not useful for production of the numeraire good. In the numeraire sector. output is still produced by unskilled labor alone, and a choice of units again makes the equilibrium wage of these workers equal to 1 . In the other sector, differentiated products are produced by a combination of unskilled and skilled labor, with a constant-returns-to-scale technology. There is a fixed supply $S$ of skilled labor. And similar factor proportions are used in manufacturing the differentiated varieties as are used in establishing the plants needed to produce these goods. Accordingly, we denote the marginal cost of producing a unit of some brand of differentiated product in the home country by $c_{h}(w)$ and the fixed cost associated with DFI by $\phi c_{h}(w)$, where $w$ is the wage paid to skilled workers.

Before turning to the political economy, let us note the requirements for equilibrium in the market for skilled labor. Each firm manufacturing differentiated products in the home country employs $s(w)$ units of skilled labor per unit of output. where $s(w) \equiv d c_{h}(w) / d w$. Each foreign multinational also employs $\phi s(w)$ units of skilled labor to establish its subsidiary. Total demand for skilled labor is the sum of demand by manufacturers and demand by foreign firms for use in building their plants.. Finally. market clearing requires that aggregate demand be equal to the inelastic supply. or

$$
\left(n_{h}+m\right) x_{h} s(w)+m \phi s(w)=S .
$$

Now we can replace $c_{h}$ in (2) by $c_{h}(w)$ and combine (2)-(4) with (15), to express the equilibrium wage as a function of the number of foreign subsidiaries and the rate of protection; we denote this relationship by $w(\tau ; m)$. Note that $w$ increases with $\tau$, because a higher tarift means greater demand for locally-produced varieties, and 
so a greater derived demand for the sector-specific labor. ${ }^{12}$. As for the relationship between the number of multinationals and the skilled wage, we see from (15) that there is a direct effect that is positive: each additional multinational demands some skilled labor to build its plant and produce its output. There is also an indirect effect that works through the induced change in $\boldsymbol{I}_{h}$. If the consumer price of domesticallyproduced goods exceeds the price of imports (as will be the case if $\tau c_{f}<c_{h}$ ). then an increase in $m$ raises the price index for differentiated products and so raises the demand for each locally produced good. In this case, the indirect effect on the wage also is positive, and the wage rate must rise as the number of multinationals expands. On the other hand, if domestic goods are cheaper to consumers than imports, $q$ falls with $m$ and so does $x_{h}$. Then DFI has an adverse, indirect effect on the demand for skilled labor. But the direct effect always dominates, and so the skilled wage always rises when the number of foreign subsidiaries increases. ${ }^{13}$

Now let us return to the politics of the situation. Given the number of foreign multinationals, $m$, both $\pi_{h}$ and $w$ increase with $\tau$. So, if both the capitalists and workers are politically organized, both will have an incentive to contribute toward protection. In contrast, while domestic profits certainly fall with an increase in $\mathrm{m}$. the skilled wage rises in response to an inflow of foreign firms. So domestic firms

${ }^{12}$ Simple comparative staties reveal that the partial derivative of $w(\cdot)$ with respect to $r$ is

$$
w_{r}=\frac{w}{\tau} \frac{(1-\eta)(\epsilon-\theta) I_{x}}{\sigma_{2}+\beta, I_{s}[\eta \theta+(1-\eta) \epsilon]}>0,
$$

where $\eta \equiv\left(n_{h}+m\right) p_{h}^{l-c} /\left[\left(n_{h}+m\right) p_{h}^{l-c}+\left(n_{l}-m\right) p_{j}^{l-c}\right]$ and $l_{x} \equiv\left(n_{h}+m\right) x_{h} /\left[\left(n_{h}+m\right) x_{h}+m o\right)$ are between zero and one, $\sigma_{a} \equiv-\mathrm{g}^{\prime} w / \mathrm{s}>0$ is the elasticity of demand for skilled labor in each of its uses, and $\beta_{0} \equiv s w / c_{h}$ is the share of skilled wages in the total cost of manufacturing differentiated products or entablishing subsidiaries.

${ }^{13}$ We calculate that

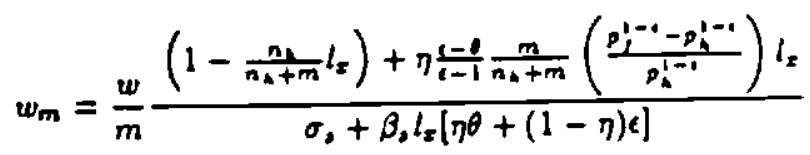

which is non-negative, because $l_{x} \leq 1$ and the terms multiplying $l_{x}$ in the numerator of the second fraction sum to something less than or equal to one. 
and industry workers will find themselves in conflict over the issue of policy toward multinationals.

How will such a conflict be resolved? To gain some insight into this issue, we focus on the extreme case where $a$ is close to zero. In the event, the government puts no weight on consumer surplus or tariff revenue and so is willing to accede to workers' and firms' demands for a prohibitive tariff. Indeed, home interest groups need pay only a tiny political contribution in order to secure a fully protected market. Foreign firms should expect an infinite tariff no matter what the degree of multinationality. ${ }^{14}$ Accordingly, we know that some foreign firms will wish to establish subsidiaries provided $\pi_{h}>\phi c_{h}(w)$ when $m=0$. It remains to be seen only whether a government that can set investment barriers will choose to impede the foreign investment.

Suppose the lobbies compete to influence the government's policy toward multinationals. Let each propose a contribution schedule linking the political gift to the number of foreign firms allowed to enter. We focus on Nash equilibrium --in which, each group's contribution schedule is optimal given the schedule of the other-and. among these, on equilibria that are not Pareto dominated for the two lobby groups. There is in fact a unique, Pareto-undominated Nash equilibrium in the situation we have described; namely, the lobby groups induce the government to choose $m$ so as to maximize the sum of the skilled wage bill and domestic profits. ${ }^{15}$

What does this tell us about investment restrictions in the ensuing political equi-

\footnotetext{
${ }^{14}$ An infinite tariff with a infinitessimal contribution is the unique Nash equilibrium when both interest groups independently set their contribution schedules. It is aiso the outcome if only one of the groups lobbies for protection.

${ }^{15}$ This conclusion follows from Theorem 2 of Bernheim and Whinston (1986). They have shown that all coalition-proof equilibria in menu-auction games maximize the joint welfare of the principals and the agent. Bere, the government is the agent and its welfare is just a transfer from the principals when $a=0$. So $m$ muat maximize $n_{h} \pi_{h}+w S$ in any coalition-proof equilibrium. Finally. the set of coalition-proof equilibria coincides with the set of equilibria that are Pareto-undominated for the principals, when there are only two principals bidding for influence.
} 
librium? To answer this question, we define $J \equiv n_{h} \pi_{h}+w S$. and calculate that

$$
J=\epsilon^{-\theta}(\epsilon-1)^{\theta-1} n_{\Lambda}\left(n_{\Lambda}+m\right)^{(\epsilon-\theta) /(1-\epsilon)} c_{h}(u)^{1-\theta}+u S .
$$

when the tariff is prohibitive. Also (15) reduces to

$$
s(w)\left[\epsilon^{-\theta}(\epsilon-1)^{\theta}\left(n_{\Lambda}+m\right)^{(\theta-1) /(\epsilon-1)} c_{\Lambda}(w)^{-\theta}+m \phi\right]=S
$$

as $\tau \rightarrow \infty$. From these two equations we can evaluate how the joint (gross) welfare of the interest groups is affected by the entry of foreign firms. We find that

$$
\frac{d J}{d m} \frac{m}{J}=-\frac{(1-\omega) m(\epsilon-\theta)}{\left(n_{h}+m\right)(\epsilon-1)}+\left[\omega-(1-\omega)(\theta-1) \beta_{s}\right] \frac{\left(1-l_{x}\right)+l_{x} \frac{m(\theta-1)}{\left(n_{h}+m\right)(\epsilon-1)}}{\sigma,+\theta \beta_{s} l_{x}}
$$

where $\omega=w S / J$ is the share of skilled wages in the aggregate income of members of the two interest groups.

Inspection of (16) reveals that joint income falls with $m$ when $\omega$ is close to zero. In the event, the political equilibrium entails a complete ban on all foreign investment. Intuitively, when $\omega \cong 0$, the sector-specific factor has only a (relatively) modest stake in the policy towards multinationals. Instead, it is the owners of domestic firms who are most affected by DFI. So the firms' lobby outbids the workers lobby in the competition for the government's favor. Of course, the situation is just the reverse when $\omega$ is close to 1 . Then an inflow of multinationals boosts the income of skilled workers and these workers have the most at stake in the outcome of the policy. In this case, the workers win the political battle and all foreign firms are free to enter. Finally, if $\omega$ is not so extreme, the political contest may give rise to compromise. The political limit to foreign entry can be found by maximizing $J$ with respect to $m$. This number will be greater the larger are skilled wages in comparison to the profits of the domestic industry (large $\omega$ ), the less elastic are firms' demands for the skilled labor (small $\sigma_{0}$ ); and the larger are the fixed costs of establishing a facility (large $\phi$, which implies a small $l_{x}$ for a given $m$ ). 


\section{Conclusions}

We have developed a model of anticipatory foreign investment that resembles in some respects the quid pro quo foreign investment described in Bhagwati (198\%). In the model, foreign investment is assumed to be irreversible while trade policies can be more readily changed. Therefore, foreign firms must base their investment decisions on their expectations about subsequent policy formation. The firms bear the extra cost of establishing subsidiaries, because they fear the eventual imposition of import barriers by the home country.

In our model, there may be no realization of a quid pro quo, because our treatment of the political economy implies no simple relationship between the number of multi. nationals and politically-determined tariff rate. Moreover, the investment process is assumed to be decentralized, so foreign firms and their government do not exploit the relationship between investment and the ensuing protection. In an equilibrium with endogenous trade policy but no impediments to DFI, the stock of foreign investment increases with the home government's taste for campaign contributions and decreases with the fixed cost of entry. Surprisingly, a government that is willing to cater more to special interests does not necessarily provide a higher rate of protection in equilibrium; this depends on how the foreign firms behave in expectation of the government's protectionist proclivities. When policy toward inward foreign investment also is politically determined, there may arise be a conflict between domestic firms wanting investment restrictions and domestic workers wanting free entry by multinationals. We have shown how various parameters influence the resolution of this conflict.

Finally, we have briefly examined a few normative issues that arise in the context of our model. We have shown for example, that DFI can be welfare improving, even if domestic manufacturing costs exceed foreign costs, so that "tariff-jumping" is the sole motivation for the investment. This conclusion is somewhat at odds with prevailing wisdom in the literature (see, for example, Brecher and Diaz-Alejandro, 1977). Our result can be reconciled with the earlier literature in view of the assumed endogeneity of protection; that is, DFI may be harmful for a given tariff rate but still beneficial if it 
induces a more liberal trade-policy outcome. We have also examined the equilibrium response to political reform. While it appreas possible that a reduction in politicians' tastes for campaign contributions might actually harm the average voter, we found no examples of such a paradox in extensive simulations of our model with different parameter values. 


\section{References}

[1] Bernheim, Douglas B. and Michael D. Whinston (1986), "Menu Auctions, Resource Allocation, and Economic Influence," Quarterly Journal of Economics, vol. 101, no.1, pp. 1-31.

[2] Bhagwati, Jagdish N. (1987), Quid Pro Quo DFI and VIEs: A Political. Economy-Theoretic Analysis," International Economic Journal, vol. 1. no. I. pp. 1-14.

[3] Bhagwati, Jagdish N., Brecher, Richard A., Dinopoulos, Elias and T..V. Srinivasan (1987), "Quid Pro Quo Foreign Investment and Welfare: A PoliticalEconomy-Theoretic Model," Journal of Development Economics, vol. 27, no. 2 , pp. $127-138$.

[4] Bhagwati, Jagdish N., Dinopoulos, Elias and Kar-yiu Wong (1992). “Quid Pro Quo Foreign Investment," American Economic Review (Papers and Proceedings), vol. 82, no. 2, pp. 186-190.

[5] Brecher, Richard A. and Carlos F. Diaz-Alejandro (1977), "Tariffs, Foreign Capital, and Immiserizing Growth," Journal of International Economics, vol. 7, no. $3 / 4$, pp. $317-322$

[6] Dinopoulos, Elias (1989), "Quid Pro Quo Foreign Investment." Economics and Politics, vol. 1, no. 2, pp. 145-160.

[7] Dinopoulos, Elias (1992), "Quid Pro Quo Foreign lnvestment and VERs: A Nash Bargaining Approach," Economics and Politics, vol. 4, no. 2, pp. 43-60.

[8] Grossman, Gene M. and Helpman, Elhanan (1994), "Protection for Sale," American Economic Review, vol. 84, no. 4, pp. ?-?. 
[9] Helpman, Elhanan (1984), "A Simple Theory of Multinational Corporations." Journal of Political Economy, vol.92, no.3, pp. 451-471.

(10) Hillman, Arye L. and Heinrich W. Ursprung (1993), "Multinational Firms, Political Competition, and International Trade Policy," International Economic Review, vol.34, no.2, 347.363.

[11] Horstmann, Ignatius, and Markusen, James R. (1992), "Endogenous Market Structures in International Trade," Journal of International Economics, vol.32, no.1/2, pp.109-129.

[12] Markusen, James R. (1984), "Multinationals, Multi-plant Economies, and the Gains from Trade," Journal of International Economics, vol.16, no. 3/4, pp.205226.

[13] Olson, Mancur (1965), The Logic of Collective Action (Cambridge, MA: Harvard University Press).

[14] Wong, Kar-yiu (1989), "Optimal Threat of Trade Restriction and Quid Pro Quo Foreign Investment," Economics and Politics, vol. 1. no. 3. pp. 277-300. 
Figure 1

\section{Equilibrium Lobbying}

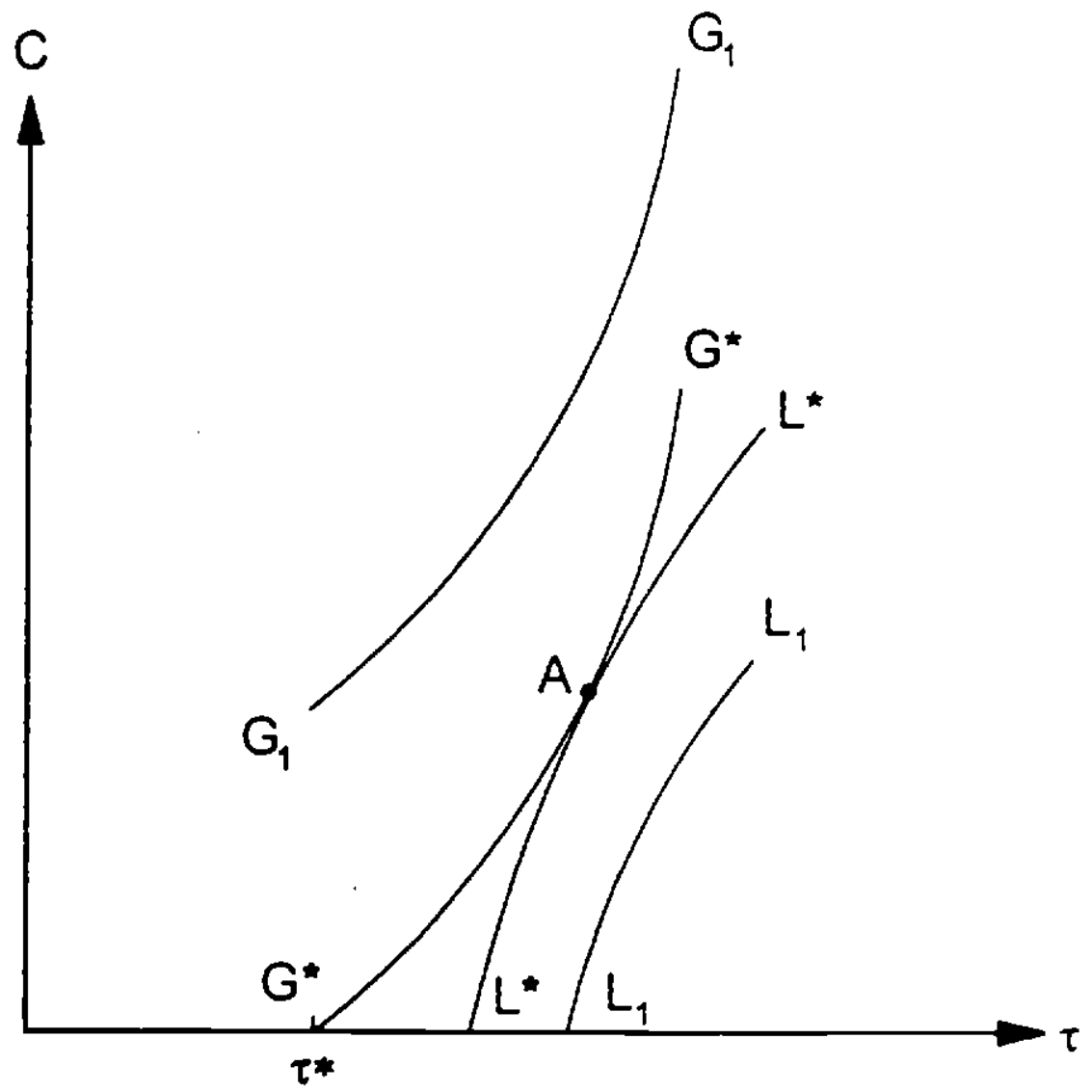


Figure 2

Political Tariff Response Curves

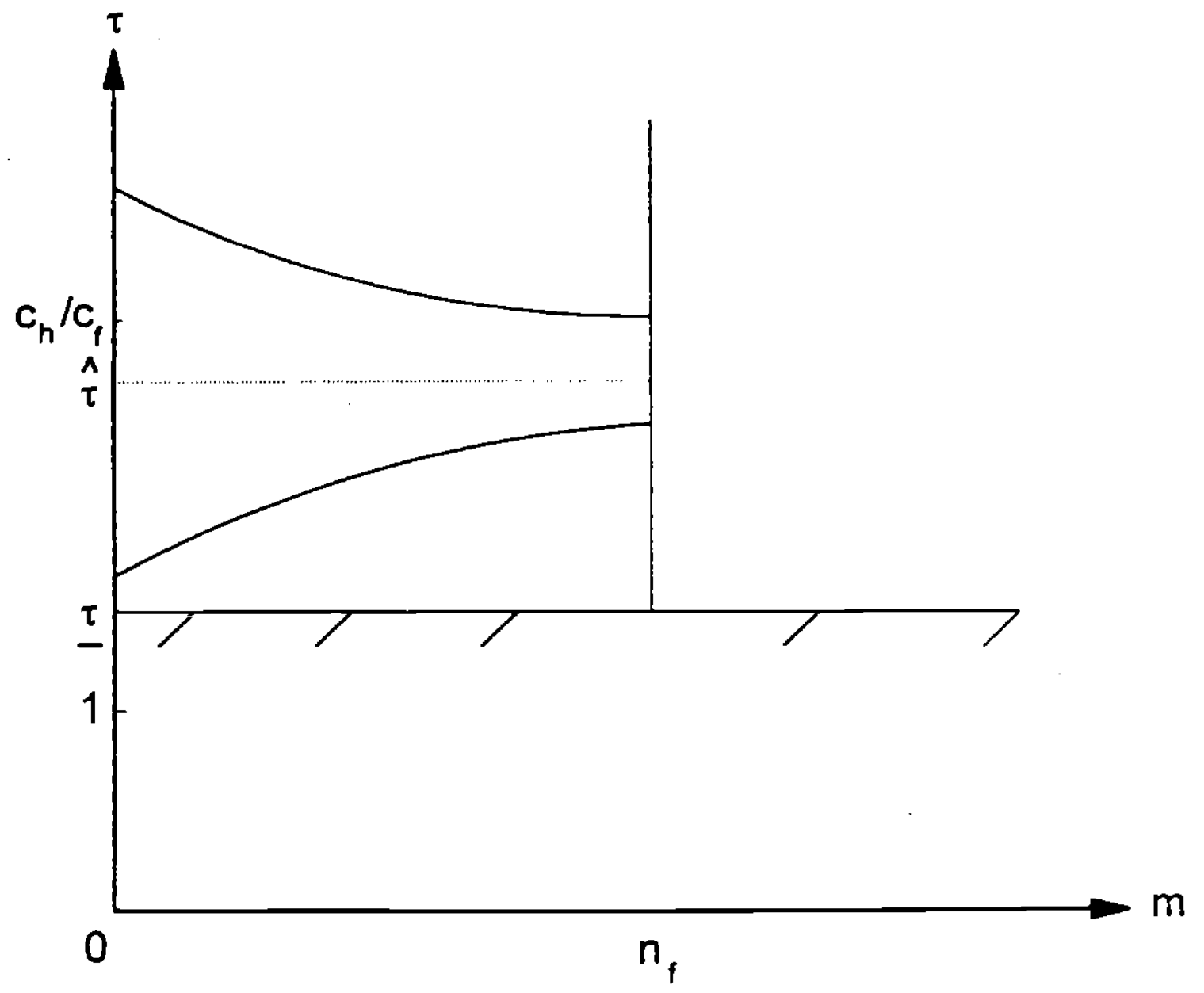


Figure 3

\section{Profit Differential Curves}

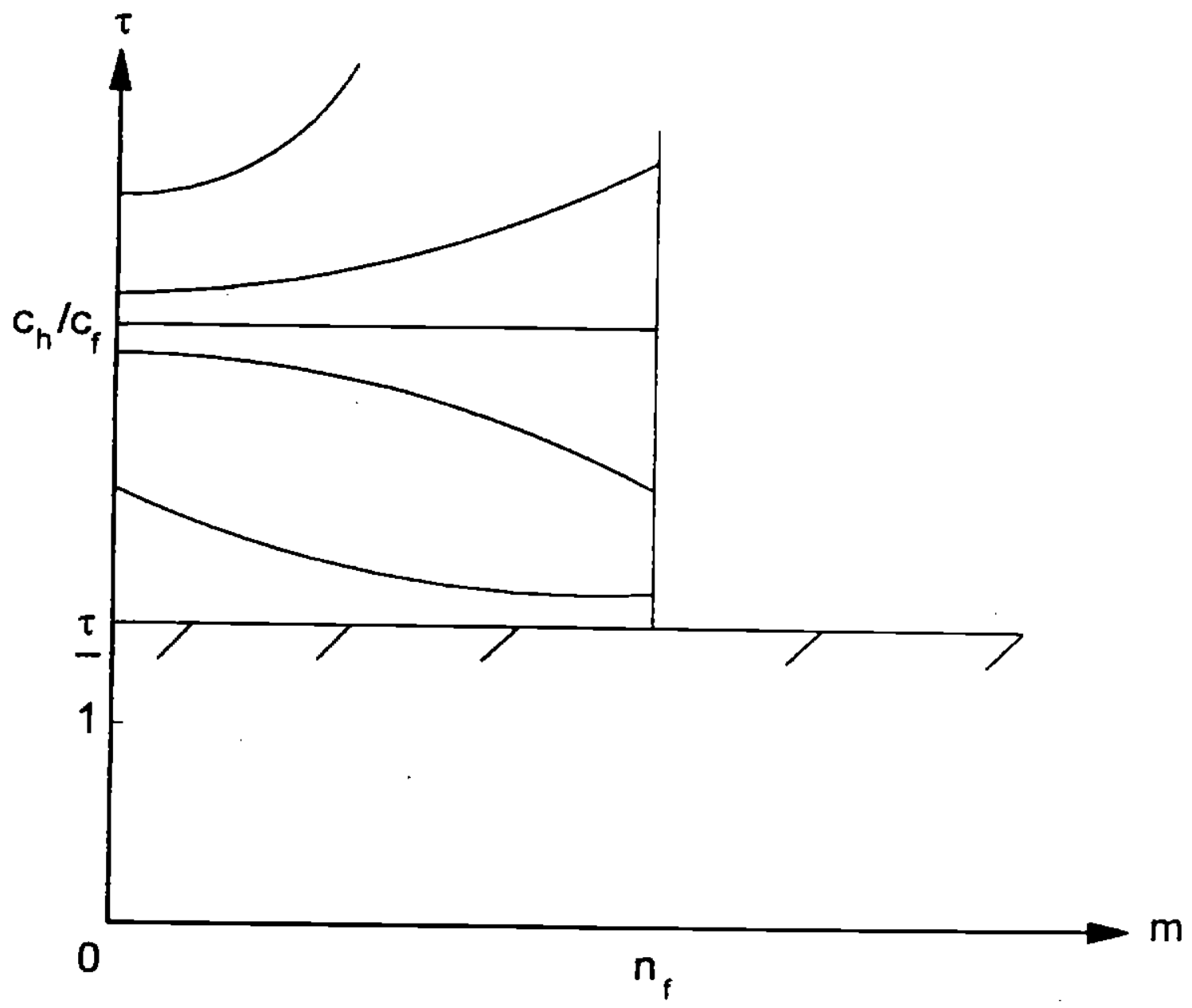


Figure 4

Equilibrium DFI and Protection

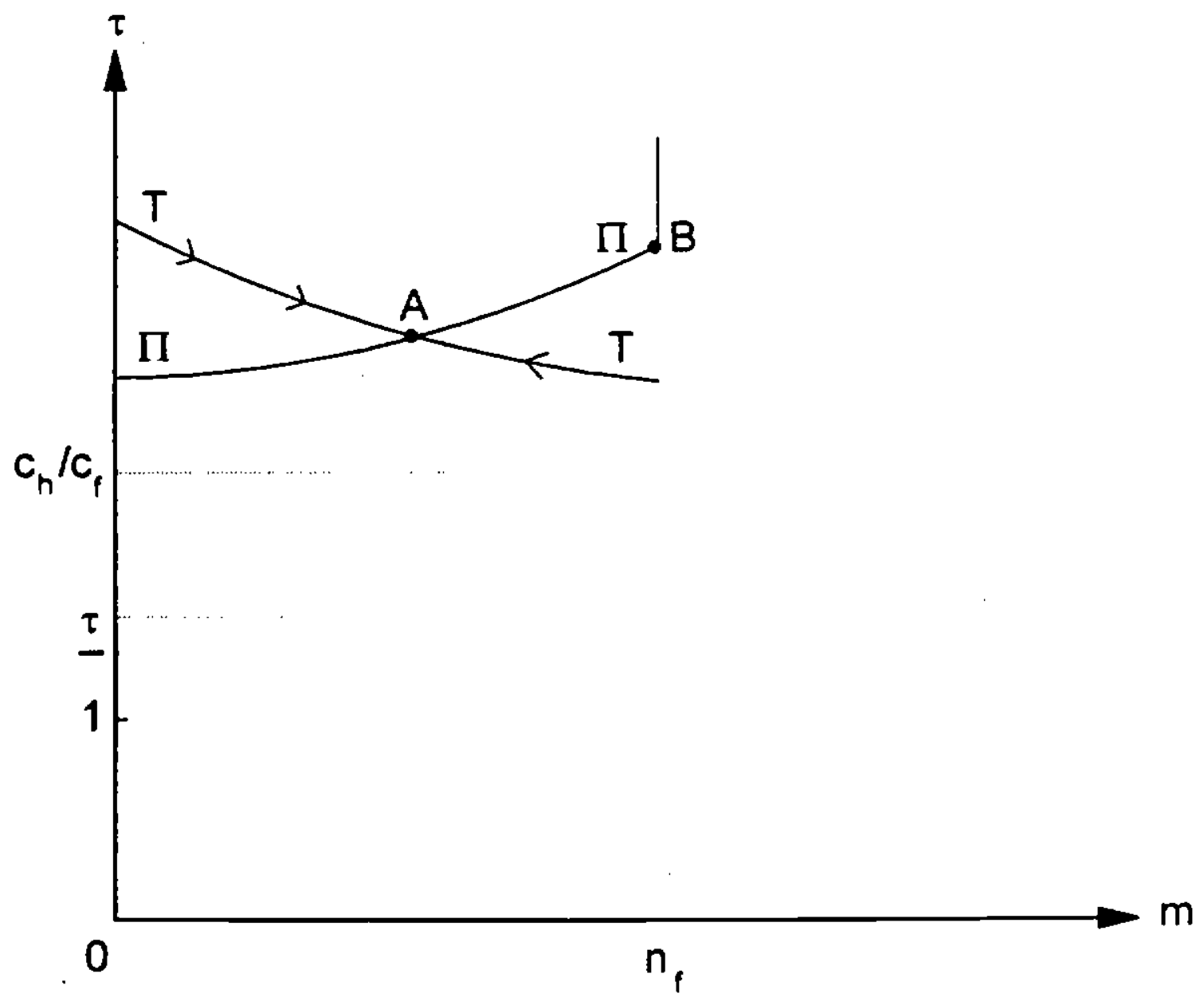


Figure 5

Altemative Equilibrium Configuration

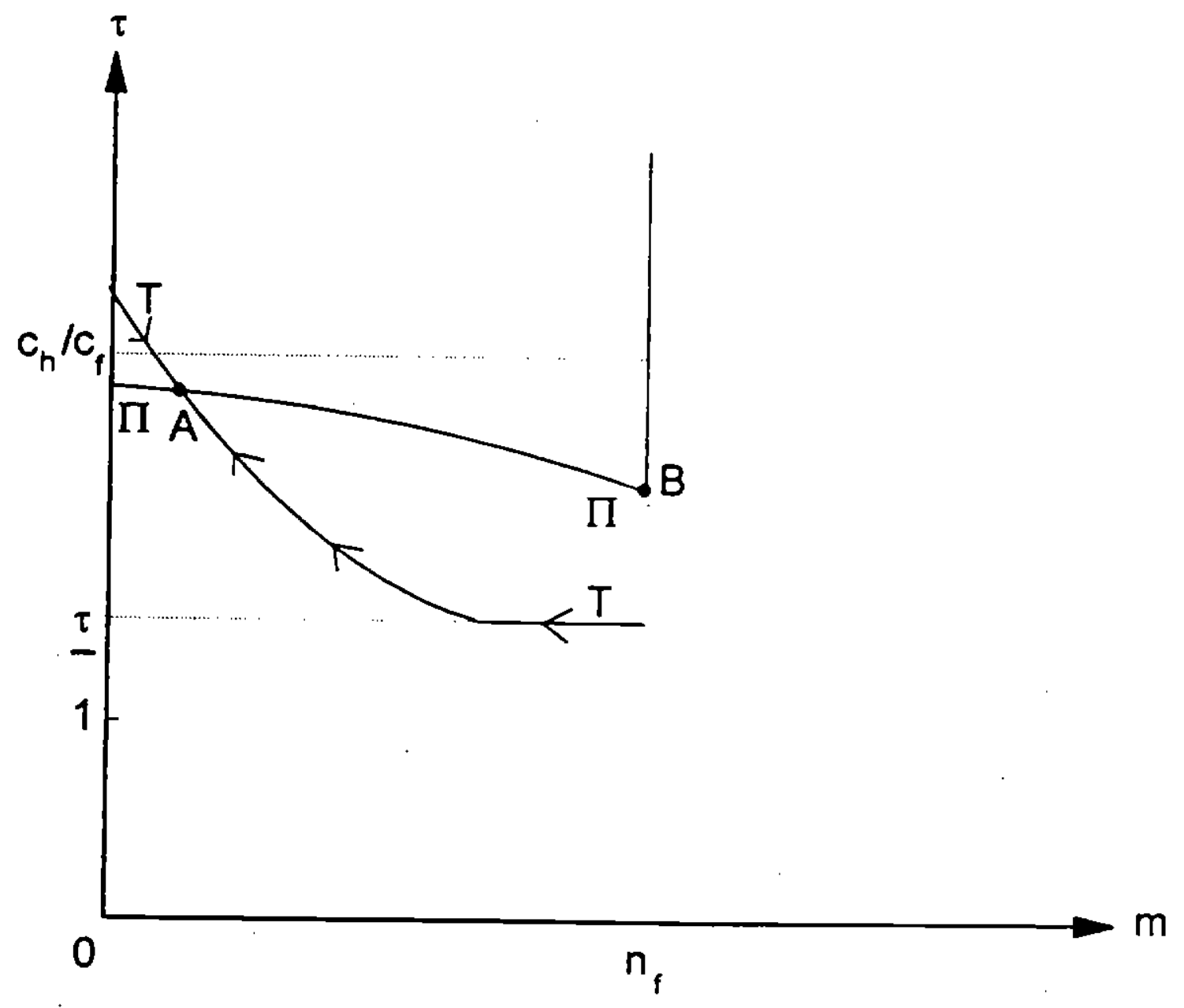


Figure 6

Multiple Stable Equilibria

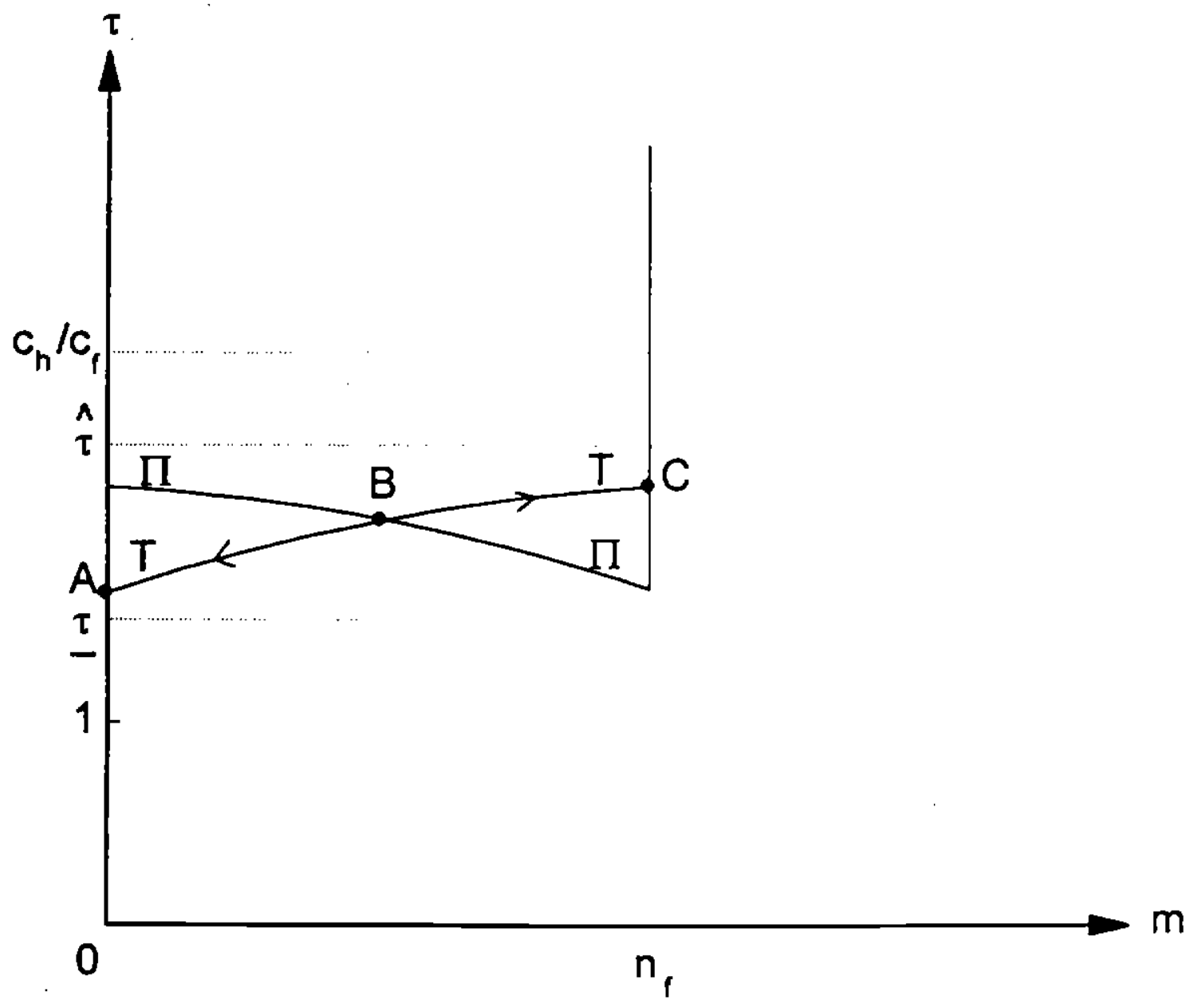


Figure 7

Welfare Effects of Political Reform

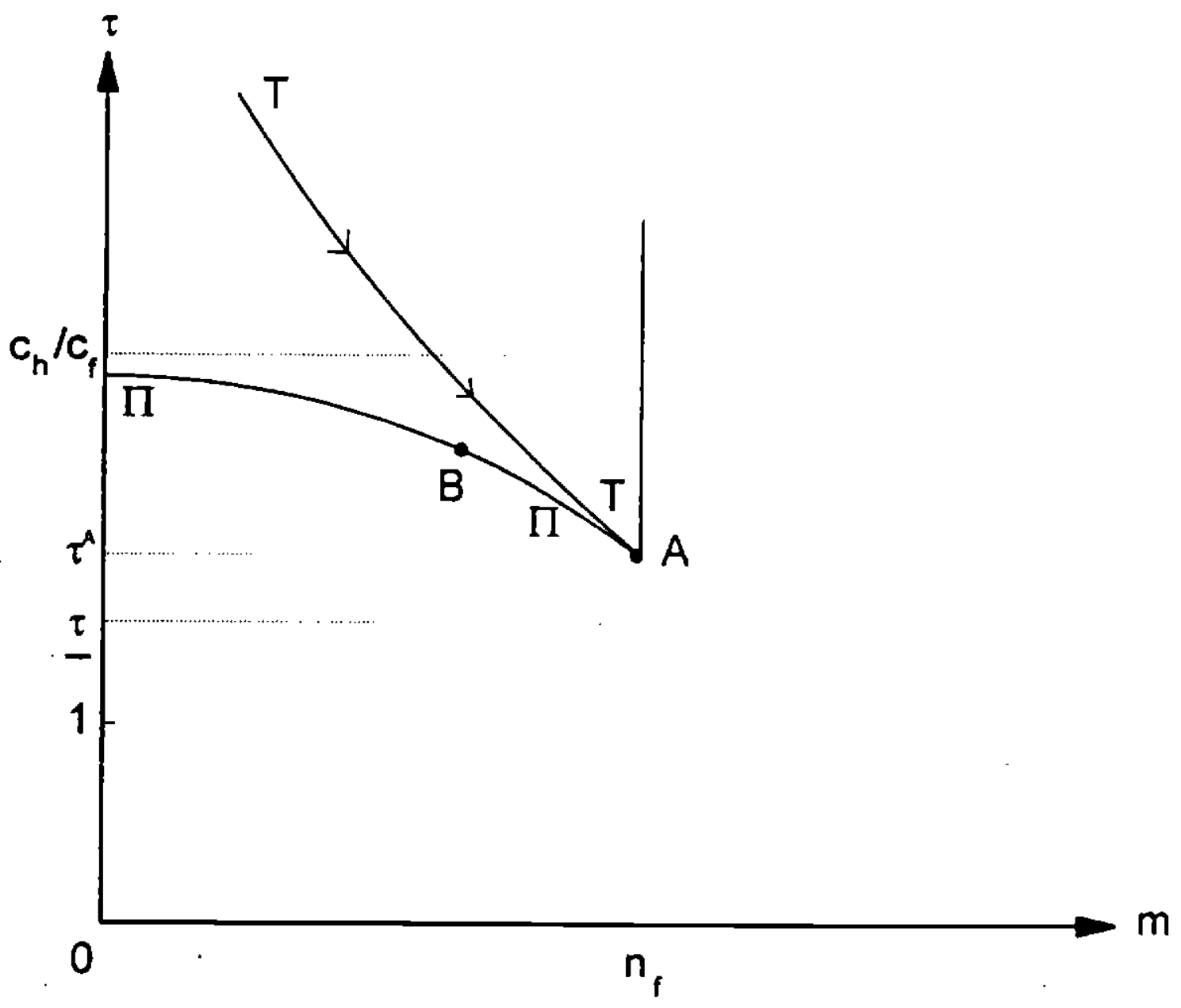

